\title{
NEW DIMENSIONS NURSING EDUCATION IN THE POST-SECONDARY EDUCATION SYSTEM IN THE REPUBLIC OF
SOUTH AFRICA
} CHARLOTTE SEARLE

\section{OPSOMMING}

In April 1982 is aangekondig dat in beginsel goedgekeur is dat verpleegkolleges met universiteite kan affilieer. Hierdie aankondiging was die kulminasie van 'n stryd wat die verpleegberoep in Suid-Afrika byna 'n eeu lank gevoer het om verpleegonderwys in die hoofstroom van die land se hoër onderwysstelsel geplaas te kry.

Dit is een van die belangrikste onlangse ontwikkelings in verpleging en die skrywer gee verskeie redes vir hierdie stelling. Sewe grondbeginsels wat die herorganisasie van professionele verpleegonderwys op diplomavlak rig en verskeie vereistes wat hieruit voortvloei, word geidentifiseer.

Die ontwikkeling van 'n verpleegonderwysstelsel wat die hoogste erkenning sal geniet bied nou 'n groot uitdaging aan die beroep.

\section{INTRODUCTION}

On April 5, 1982 in her capacity as rresident of the South African Nursing Association, the author received a letter from the then Minister of Health. Dr. the Hon. L A P A Munnik to inform her that the Minister of Education had submitted the information to him that the Advisory Council of the Universities of South Africa had approved the principle whereby universities could develop an association with nursing colleges on the same lines as exist in respect of teacher training colleges, that is, as colleges external to the university but linked on an academic level to the university concerned.

The Minister of Education indicated that the Department of National Education would proceed immediately to draw up the necessary guidelines for such affiliation and that the relevant health authorities should immediately proceed with negotiations with the universities to establish the links between the nursing colleges and the universities of their choice.

This letter, which ushered in a new era in nursing education and hence in nursing development in South Africa, is the culmination of a struggle waged by the nursing profession for close on a century. The nurses of this country not only owe a tremendous debt to those nurses who have so gallantly fought for a sound educational system for nurses. They also owe a debt to the members of the Health Matters Advisory Committee and the National Health Policy Council, the Advisory Committee of the Universities and the Committee of University Principals who gave such staunch support to the proposed developments.

The above decision is probably the most momentous that has been taken for the development of nurs ing in South Africa in this century.

The establishment of nursing degree courses at South African universities was a step of major significance in the development of nursing in this country, but it must be remembered that degree courses are provided for a select few. The linking of the education of all professional nurses with a university system is of the utmost importance to the profession - it will affect the professional life of all nurses, not only of those who train under the new system.

\section{OVERVIEW}

A brief overview of the long struggle that has culminated in this decision is essential to illuminate its significance for all professional nurses.

For close on a century the nursing profession has struggled to obtain the same privileges and status for nursing education as applies to the education of teachers. As far back as 1889 Sister Henriëtta Stockdale aided by Dr John Mackenzie of Kimberley, made representations to the Superintendent-General of Education in the Cape Colony to provide training grants for pupil nurses on the same lines as for pupil teachers, to accept nursing education as part of the general education system of the country, to prescribe the syllabus of training and to conduct examinations and award certificates (Letters and Notes in possession of the late Sir David Harris, and Report of the Colonial Medical Committee on Government Hospitals and Asylums 1890). She clearly indicated that this would keep nursing education related to the needs of the community.

From the establishment of the South African Trained Nurses' Assocation in 1914, right up to the representation which at last achieved 
the desired goal in 1982 , the nursing profession has struggled to make nursing education truly comprehensive to meet the nation's health needs, to separate the control of nursing education from the control of nursing service and to place nursing education within the sphere of influence of universities, by means of the establishment of departments of nursing in universities for education at degree level and by linking nursing colleges with universities for education of professional nurses at diploma level.

One of the first actions of the newly established South African Nursing Council in 1944 was to examine the education and training of nurses. By 1946 it had made representations to the Minister of Health, the universities and the provincial authorities. It indicated that comprehensive education and training of nurses in all four disciplines (general, midwifery, psychiatric and public health) was essential and that this education should take place in universities and in nursing colleges affiliated to universities. Such colleges should in every respect be at least equal to the teacher training colleges maintained by the various provincial administrations. At the same time the Council pin-pointed the need for the appointment of professors of nursing at the universities and of directresses of nursing services in the provincial departments of hospital services. All authorities including the universities, recognised the importance of these recommendations. It was nevertheless not possible to implement the proposals for the new form of nursing education due to:

- the statutory division of responsibility for the provision of health care, which prevented the development of comprehensive health services and consequently the provision of comprehensive nursing education programmes

- the ingrained concept of service for education that characterised the hospital nursing school system

- the lack of a national policy on nursing education

- financial stringency due to the post-war economic situation in the country

- the small number of young women who had matriculated in South Africa prior to World War II, due to the inadequate provision of secondary school facilities beyond the limits of the larger urban communities.

Many factors have however combined to exert pressure for change and have convinced the authorities that diploma nursing education must be placed on a par with that of teacher education.

These are:

- the great increase in the number of girls of all population groups who complete the requirements for the senior secondary education certificate (that is 12 th grade) but at the same time the drop in recruitment of student nurses into the existing nursing education system

- pressure by the South African Nursing Association and the South African Nursing Council on health and on university authorities to implement a system of modern nursing education which would be acceptable to the youth of South Africa, to the public and to nurse educators, and that would keep abreast of the advances in medical sciences and of health care needs

- statements by various Ministers of Health that the comprehensive health care system is built around the concept that nurses will be the main providers of health care, thus necessitating a comprehensive approach to the education and training of the nurse

- the increased awareness of nurse educators of the benefits of a university, or a university-linked, system of nursing education

- the shortage of nurses and the high attrition rates amongst student nurses in the present system

- the shortcomings of the national examination system with its inevitable delay in publishing the results of the final examination thereby affecting the income of the nurse who has completed her course, as well as depriving the health services of urgently needed registered nurses

- the problems encountered in reconciling the instructional/learning objectives of individual colleges with a national system of examination

- the goodwill of the Ministers of Health and of Education, the university authorities, the DirectorGeneral for Health and Welfare, and the Directors of Hospital Services towards the nursing profession - the goodwill of the Cabinet towards the profession due to the responsible attitude of the SA Nursing Association and the SA Nursing Council in managing nursing problems

- the aspirations of modern youth for an education system that will equate with other systems of professional education

- the need to introduce a system of education for nurses at diploma level that will allow for creditation of some subjects in the diploma nursing courses for education in other directions or at other levels

- the introduction of the Health Act No 63 of 1977, the implementation of which needs nurses prepared at a comprehensive level and which now makes it possible to provide a system of comprehensive education for nurses

- the recommendations of the Van Wyk de Vries Commission of Inquiry into Universities which expounded the view that colleges of nursing could be affiliated to universities on the same lines as teacher training colleges are affiliated or as the Commission proposed for technikons (CATE).

\section{Important considerations}

In making representations to the autherities for the introduction of a nursing college system linked with universities, both the South African Nursing Council and the South African Nursing Association had to consider several issues in addition to the above, namely:

- the need for a national policy on nursing education

- the need for nursing education to receive its just share of the taxpayer's resources and the placement of the nursing education system within a recognised system of education. (It is an international viewpoint that nursing education should be in the main stream of education) 
- the most beneficial alternative for nursing education in the long run from the point of view of financing both the system and the student nurse

- which system would be the most desirable to ensure that the student is equipped socially, theoretically, clinically and as a professional practitioner to meet the nation's diverse health needs

- the clarification of the status of the student within the universitycollege-health care system with particular reference to the amount and nature of the clinical practica that is needed to produce a competent nurse

- the nature of an academic affiliation between a university and a nursing college, so that the autonomy of the authorities providing the financial backing is not jeopardised but that a valid educational system is ensured at the same time - the need to identify clearly that nursing education is part of the postsecondary (or tertiary) education system in this country.

How have these issues been resolved?

\section{THE POLICY DECISION}

The decision of the National Health Policy Council (the highest policymaking authority in the health field), and the acceptance by the Minister of Education and the Advisory Committee of Universities, (the highest policy-making authorities in the field of education) that nursing colleges offering professional nurse training at diploma level may be linked to universities, along the same lines as pertain to teacher training colleges, constitute a policy for nursing education which has far-reaching implications.

The most important aspects of this decision are that:

- professional nurse training at diploma level belongs squarely in the post-secondary stream of education, and is being accorded its rightful status in this regard

- the State and provincial health authorities would continue to finance nursing education from funds appropriated from tax-revenues both in regard to the financing of the colleges and the financing of student nurses

- the nursing profession is entering a new era in professional education and development and the profession has, as an additional dimension, been accorded the recognition it so justly deserves.

More-over the provisions of the Health Act No 63 of 1977 and the acceptance by the Minister of Health and other health authorities of the key role of the nursing profession in the provision of a comprehensive health service have finally clarified and confirmed the need for the comprehensive education and training of the registered nurse.

\section{THE STATUS OF THE STUDENT NURSE}

Both the SA Nursing Council and the SA Nursing Association recommended that students on all basic nursing courses, should be given de facto and de jure student status. The student should register with the college and not with the hospital, and for the full duration of the course she would fall under the control of the college for the implementation of her programme and ipso facto under the supervision of the associated university.

This does not mean that she will not fall under the control of the matron whilst she is a member of the clinical team in the hospital situation. In the final analysis the particular health care authority accepts the responsibility for the care provided for its patients, and for the acts of omission and commission of those members of the health team who are financed by the authority, whether this is as paid staff members, student staff members, or as contract officers receiving reimbursement from the authority concerned.

This type of dual responsibility works very well in respect of the students on degree courses where the closest co-operation exists between the university and the health authority concerned. (The author believes that the chief matron of a large health care complex should hold associate or honorary professorial status in a university department of nursing science and similarly in a college. This would clarify the educational link between the university or college and the health care facility in respect of the control of the clinical practice and would give due recognition to the important role of the chief matron in the total educational programme. However, this is something for the future).

Both the abovementioned nursing bodies emphasised that they do not subscribe to the concept of supernumerary status of students. They claim that student status cannot be supernumerary status, no matter what is said in other parts of the world. Observers are never true participants or learners. They be lieve that the student strength should be complementary to basic staffing requirements with a formula of $X$ regular nursing staff and $Y$ number of students. The educational authority responsible for the nursing education programme should determine what type and amount of clinical learning experiences are required to meet the registration requirements, the national needs and the objectives of the particular programme. The heads of nursing education and nusing service should work out the strategies for the organisation of theory and practica together.

The Council and the Association subscribe to the concept that true student status lies in the approach to the student and to her development which sees her as a responsible, thinking individual who understands the logic of nursing discipline and understands how to utilise nursing knowledge and resources and who accepts responsibility for her own education. Both authorities emphasise that the learning needs of the student and not the service needs are of paramount importance in planning the teaching/learning strategies in the clinical situation. The National Health Policy Council accepted this viewpoint. It is envisaged that the new regulations of the SA Nursing Council will provide guidelines for minimum practica requirements.

\section{THE NATURE OF AFFILIATION}

In determining the nature of an academic affiliation between a univer- 
sity and a nursing college a study of: - the memoranda advocating a system of linking of nursing colleges with universities

- the decisions of the National Health Policy Council, and

- the approval of the Minister of

Education for this development

cleary indicated that there are seven fundamental principles that give direction to the reorganisation of professional nursing education at diploma level.

\section{The seven fundamental principles}

The following principles were identified:

- the principle is entrenched that professional nursing education at diploma level is part of the national system of post-secondary (tertiary) education

- separation of nursing education from the control of nursing service, with the removal of the control of the nursing colleges from the control of hospitals and their establishment as institutions of education directly responsible to the authority financing them

- colleges will be linked closely with the hospitals and non-institutional health services that will provide the clinical learning experiences for the student. There will be close interdigitation of the activities of the colleges with the activities of the health services which provide the clinical practice field for students

- a college will be linked academically to the university selected by the authority financing the college and the Minister of Education will approve the conditions of affiliation in respect of each college

- nursing education and training must be comprehensive to meet the health needs of the country. Such comprehensiveness implies that basic courses should include general nursing, psychiatric nursing, midwifery and community nursing as complete disciplines

- within the South African system it is imperative that the student is involved in a broad range of institutional and non-institutional health care activities and that clinical learning experiences shall, as in the past, constitute a major component of the total learning experiences of the student. The student must participate in the patient care situation as a member of the ward, department or clinic team

- all courses offered must meet the academic requirements of the affiliated university as well as the minimum requirements prescribed by the SA Nursing Council. The Council retains its right of inspection.

\section{Requirements}

Implementation of the new system within the parameters of all the principles enunciated in the preceding paragraphs requires that:

- a nursing college be established within the enabling legislation of the authority responsible for its establishment. Such a college should in every respect be equal to and have a status equivalent to that of the teacher training colleges (Colleges of Education) of the province concerned

- the college should have its own budget and be financed in full by the authority concerned

- the college should have a college council and a faculty board or even a senate equal to that of the teacher training colleges in the particular province. It is envisaged that the members of the college Council could be drawn from personnel of the controlling authority, from superintendents and matrons representing hospitals and service organisations linked to the scheme, school principals, other influential members of the public, and representatives of the university with which the college is linked academically

- only basic and post-basic professional nursing education be linked to the university. Where a college wishes to provide sub-professional courses it must set up a separate system, not linked with the university and must provide qualifications that are not linked with the name of the university concerned

- students will be registered as students at the nursing college and not at any of the hospitals which provide clinical experience. The educational locus is the college and the students will be college students despite the fact that provincial or state authorities will provide salaried training posts on the same lines as is now done for medical student interns and medical graduate interns

- there must be close co-operation between the head of the college and the hospital and health service authorities providing the field of practice for clinical learning experiences in order to ensure smooth interdigitation of theory and practice and optimal utilisation of available hospital and other health care facilities

- the contribution of the university with which a college is linked will be determined by an agreement between the university and the authority responsible for the college. In broad outline this will include such issues as:

maintaining academic standards by means of further education of college personnel, inter-library facilities, assistance with research and co-operation in the development of curricula that not only meet the requirements of a comprehensive health service and of the SA Nursing Council, but which will also ensure a system of credits for the student who wishes to proceed with her education. The university will also act as external examiner to the college-based examinations. This will enable each college to conduct its own examinations and the need for the national examinations of the SA Nursing Council will fall away. To facilitate the academic process, the university would have representatives on the college council and the head of the nursing college would serve on faculty boards or even on the senate of the university concerned.

It must be clearly understood that linking of a college with a university does not mean that the college becomes part of the campus of the university. It is an academic link on the same lines as exist between the universities and the teacher training colleges. Each partner remains autonomous and in control of its own facilities and activities.

\section{Other aspects}

It is important to note that colleges will have to obtain services from the 
existing provincial complex, in the same way as the Wits Medical School obtains certain services from the provincial hospital complex in which it is situated. The principle of sharing facilities provided by the same or by a related organisation is well-established. In this type of link the smaller organisation is a purchaser of supplies and facilities from the larger or adjacent organisation.

The advantages to the nursing profession of this type of development are manifold. The primary advantage lies in the improved system of education and training for the profession, and all this entails. Nevertheless, major advantages are also possible for the teaching personnel, and the nursing profession must fight to ensure that nursing college personnel obtain the same advantages as apply to the personnel of teacher training colleges. The profession must not be satisfied with less. If the head of a teacher training college has the rank of professor, the same principle should apply to the head of a nursing college.

It is self-evident that existing college personnel, whether they hold degrees or not are secure in their tenure. Rome was not built in a day. Experience and existing postbasic nursing qualifications must, and will receive due recognition, although degrees will be an inevitable requirement for those replacing existing personnel who proceed on retirement.

\section{THE IMPACT OF THE DE LANGE COMMISSION}

The decision of the Minister of Education was given just in time to stave off an absolute disaster to the credibility of nursing education in South Africa viewed against the forward-looking recommendations of the De Lange Commission. Under the definitions given by this Commission of formal and non-formal education and if its major recommendations are accepted by the government the present system of nursing education is faced with the fact that it will be classified as nonformal education unless its colleges are absorbed in some way into the main stream or higher education. As definitions are non-controversial we have to realise that these definitions which are widely accepted in educational circles will present no problems to the policy makers of the country. The two critical definitions are:

- formal education is education that takes place in recognised educational institutions such as schools, colleges, technikons and universities and proceeds in a planned manner

- non-formal education is education which is planned and highly adaptable and takes place in institutions, organisations and situations outside the formal and informal education provisions, such as in-service education in the work situation.

Loss of credibility as formal education, because hospitals are not formal educational institutions, would have disastrous repercussions on recruitment of students, on the status of tutors, on recognition of nursing qualifications by teachers, the academic community and by the Commission for Administration. Existing post-basic, clinical nursing qualifications would also have the status of non-formal education courses. The only valid courses in nursing education would be those offered at universities and at technikons.

There is therefore a clamant need for nursing colleges to be recognised as formal education centres with the necessary academic status.

It is gratifying to note that in one of the latest SAPSE (South African Post-Secondary Education) documents relating to university education it is clearly stated that, in this reorganised system of education, academic communities in South Africa will be universities, technikons, teacher training colleges and nursing colleges. Other types of colleges, such as theological colleges and agricultural colleges may be added to this list at a later stage.

Another issue of grave importance is the recommendation that a South African Council for Education be established on which a variety of educational organisations as well as the community and pro- fessional associations will be represented. It was envisaged by the Commission that this Council would be served by a series of expert committees, one of which would be a curriculum committee for higher education. The Commission listed universities, technikons, teachers, nursing and agricultural colleges as examples of participants in such a committee. The Commission recommended various other committees such as a committee for rectors of teacher training colleges, for directors of technikons, and for heads of universities. Obviously a committee for heads of nursing colleges is a must.

Another issue of importance is the proposed establishment of a register of all qualified teachers in South Africa. It is recognised that teachers may have to register on the register of their professional controlling authority (e.g. the SA Nursing Council, or the SA Medical Council) as well as on the national register of teachers.

Nurse educators cannot afford exclusion from such a national register.

\section{THE CHALLENGE}

Viewing South African developments, and comparing them with the developments and constraints of the nursing education system in some other Western countries, they offer the nursing profession and the consumers of health care an outstanding method of providing an educationally valid, purpose-effective nursing education system that will compare with the best in other countries and that will be within the financial resources of the community and the prospective student.

The nursing profession is being faced with an unprecedented challenge. If we believe that nursing education and training should have the same status as that of other professional education, and if we believe in ourselves and in the future of our profession we will accept the challenge and prove that we are able to develop an educational system that will enjoy the recognition of the highest educational authorities in this country. All uni- 


\section{RENEWAL IN THE SYSTEM OF NURSING EDUCATION}

versities are proud of their nursing education departments. The next step is to make them proud of their link with the nursing colleges.

We have the opportunity to develop a new model of nursing education within the tertiary education system of this country. This model is unique in the Western world. It is tailored to the needs of Africa. Surely nurse educators and nurse administrators will tackle this new approach with vigour and insight in a mutually co-operative spirit. The future is ours - what are we going to make of it?

\section{REFERENCES}

1. Letters and notes in possession of Sir David Harris 1937 and Report of the Colonial Medical Committee on Government Hospitals and Asylums 1890.

2. Records of the SA Trained Nurses' Association.

3. Records of the SA Nursing Council, 1946.

4. Memorandum by the SA Nursing Associ- ation to the SA Nursing Council on Aspects of the system of nursing education and on sections of the main Report of the Commission of Inquiry into Universities and the relevance thereof for nursing education.

5. Records of the SA Nursing Council 1977: representations to the Minister of Health and to the directors of hospital services $109 / \mathbf{S 7 7}$.

6. Records of the SA Nursing Association: various memoranda to the Minister of Health.

7. RGN: Onderwysvoorsiening in die RSA 1981. RGN Pretoria 1981 